\title{
Abundance and richness of Arctiinae moths throughout the night in a Cerrado area
}

\author{
Carolina Moreno $^{1}$, Angela S. Barbosa ${ }^{2}$ \& Viviane G. Ferro ${ }^{3 *}$ (1) \\ ${ }^{1}$ Biota Projetos e Consultoria Ambiental Ltda. Rua 86-C, 64, Setor Sul, 74083-360, Goiânia, GO, Brasil. \\ ${ }^{2}$ Universidade Federal de Goiás, Instituto de Ciências Biológicas, Departamento de Ecologia, 74001-970, \\ Goiânia, GO, Brasil. \\ ${ }^{3}$ Universidade Federal do Rio Grande do Sul, Instituto de Biociências, Departamento de Zoologia, Av. Bento \\ Gonçalves 9500, prédio 43435, sala 227, 91501-970, Porto Alegre, RS, Brasil. \\ *Corresponding author: vivianegferro@gmail.com
}

MORENO, C., BARBOSA, A.S., FERRO, V.G. Abundance and richness of Arctiinae moths throughout the night in a Cerrado area. Biota Neotropica 21(2): e20201041. https://doi.org/10.1590/1676-0611-BN-2020-1041

\begin{abstract}
The main goal of this work was to investigate how the abundance and richness of Arctiinae moths varies over time, during the night. Specifically, we analyzed the following questions: (1) Is there a relationship between Arctiinae abundance and richness with the temperature and relative humidity? (2) What are the hours of activity of each species of moth? (3) Does the species composition differ over night? (4) Is it necessary to sample this group of moths throughout the night to have a representative sample of the species? We sampled the moths in Emas National Park (17 $49^{\circ}-18^{\circ} 28^{\prime} \mathrm{S}$ and $\left.52^{\circ} 39^{\prime}-53^{\circ} 10^{\prime} \mathrm{W}\right)$, Brazil. We selected seven sampling points in an area of savanna. At each sampling point, we collected the Arctiinae moths with a light trap (with a 15-W black light fluorescent light bulb), reflected in a white cloth $(2 \times 3 \mathrm{~m})$ extended vertically. We sampled the moths in seven consecutive nights (one night in each sampling point, from December 13 to December 19, 2012, from 7 p.m. until 7 a.m.). We divided the samplings in twelve periods over the night, with an hour each. At each period of time, we measured the temperature and the relative humidity with a digital termohygrometer. We sampled 149 individuals belonging to 17 species of Arctiinae moths. Most species (70.5\%) were active only for one or two hours at night. The species differed in terms of time activity. The higher abundance occurred at 8 p. m. (44 individuals), followed by 38 individuals at $9 \mathrm{p}$. m. and 23 at $10 \mathrm{p}$. m. The species richness was also higher in the early hours of the night. The temperature was the only variable that showed a positive and significative relationship with the Arctiinae moth abundance. The species richness was not influenced neither by the temperature nor by the relative air humidity. The possible causes of the peak of abundance and species richness in specific hours of the night are discussed. Keywords: Lepidoptera; nocturnal activity; relative humidity; temperature; temporal partition.
\end{abstract}

\section{Abundância e riqueza de mariposas Arctiinae ao longo da noite em uma área de Cerrado}

Resumo: Este trabalho teve como objetivo principal investigar como a abundância e a riqueza de mariposas Arctiinae variam temporalmente, ao longo do período noturno. Especificamente, analisamos as seguintes questões: (1) existe relação entre a abundância e a riqueza de Arctiinae e a umidade relativa do ar e a temperatura? (2) qual é o horário de atividade de cada espécie de mariposa? (3) a composição de espécies difere ao longo da noite? (4) é necessário amostrar esse grupo de mariposas ao longo de toda a noite para ter uma amostra representativa das

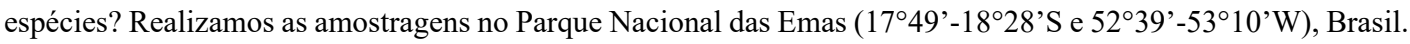
Selecionamos sete pontos amostrais em uma área de campo cerrado. Em cada ponto, coletamos as mariposas Arctiinae utilizando uma fonte luminosa (lâmpada UV de $15 \mathrm{~W}$ ) refletida em um pano branco ( 2 x 3 m) estendido na vertical. Coletamos as mariposas durante sete noites consecutivas (uma noite por ponto, entre os dias 13 e 19 de dezembro de 2012, das 19:00 até as 07:00). Dividimos o período noturno em doze faixas de uma hora. Medimos a temperatura e a umidade relativa do ar com auxílio de um termohigrômetro digital. Amostramos 149 indivíduos pertencentes a 17 espécies de mariposas Arctiinae. A maioria das espécies (70,5\%) esteve ativa apenas por uma ou duas horas durante a noite. As espécies diferiram em termos de horário de atividade. $\mathrm{O}$ horário das $20 \mathrm{~h}$ apresentou uma maior abundância (44 indivíduos), seguido do horário das 21 (38) e das 22 h (23). A riqueza também foi maior nas primeiras horas da noite. Somente a temperatura foi positivamente correlacionada com a abundância de mariposas. A riqueza de mariposas não foi influenciada nem pela temperatura nem pela umidade relativa do ar. As possíveis causas das diferenças em termos de horários de atividade são discutidas..

Palavras-chave: Lepidoptera; atividade noturna; umidade relativa; temperatura; partição temporal. 


\section{Introduction}

Patterns of abundance and species richness vary both spatially and temporally (Silva et al. 2011). Several factors may influence these patterns, such as climate, the distribution of resources and the intra and interspecific interactions (Wolda 1978, Pinheiro et al. 2002). In the tropics, the abundance of insects in mainly determined by abiotic factors, such as temperature, air humidity, precipitation and photoperiod (Wolda 1988, Axmacher et al. 2009).

Generally, environments with precipitation and temperature uniformly distributed throughout the year, present a low temporal variation in the abundance and richness of species. In a humid forest in Ecuador, for example, the abundance of Arctiinae moths did not differ among the seasons (Hilt et al. 2007). However, in environments with two well-defined seasons (hot and cold or rainy and dry), there is usually a significant temporal variation in abundance and species richness. In Atlantic forest, for example, the abundance and richness of butterflies are related to temperature, being higher in the warmer period of the year (Ribeiro et al. 2010). In Caatinga biome, Sphingidae moths are more abundant in the rainy season, being practically absent in the dry season (Gusmão \& Creão-Duarte 2004).

The Cerrado biome presents a bimodal climate in relation to the distribution of rainfall periods and temperatures (Ramos-Neto \& Pivello 2000, Silva et al. 2008). During the months of April to September (dry season), monthly rainfall ranges from 49 to $79 \mathrm{~mm}$, and the monthly temperatures ranges from 15 to $19^{\circ} \mathrm{C}$ (Ministério da Agricultura 1992, Ramos-Neto \& Pivello 2000). From October to March (rainy season), the monthly rainfall ranges from 111 to $197 \mathrm{~mm}$ and the monthly temperatures ranges from 19.4 to $22.5^{\circ} \mathrm{C}$ (Ministério da Agricultura 1992, Ramos-Neto \& Pivello 2000). Several families of insects show a seasonal pattern in their abundances, being significantly higher in the rainy season (Pinheiro et al. 2002, Oliveira \& Frizzas. 2008). However, Lepidoptera larvae show population peaks in the dry season (Morais et al. 1999) and adult lepidopterans do not show difference in abundance throughout the year (Pinheiro et al. 2002, Oliveira \& Frizzas 2008).

Most studies on the temporal variation of diversity focus on the fluctuations in richness and abundance throughout the year, with few studies dealing with the daily variation of these two parameters (ex. Scherrer et al. 2013, Camargo et al. 2016). Studies on the daily activity of species are important to answer technical questions (such as to know the best period for sampling a specific species), as well as for scientific questions, such as niche temporal partition and co-occurrence patterns.

The order Lepidoptera (butterflies and moths) has more than 160 thousand described species (Van Nieukerken et al. 2011). This taxon has great relevance in terrestrial ecosystems, acting mainly as herbivores and pollinators (Scoble 1995). Among lepidopterans, the Arctiinae subfamily is one of the most diverse (Heppner 1991, Weller et al. 2009). Arctiinae is composed by approximately 11,000 species of moths distributed worldwide (Scoble 1995, Weller et al. 2009). Approximately six thousand species are found in the Neotropical region (Heppner 1991) and 1,400 species were sampled in Brazil (Ferro \& Diniz 2010). In the Cerrado biome, there are records of 723 species (Ferro et al. 2010), and in Emas National Park, around 150 species were already registered (Moreno \& Ferro 2016, Moreno et al. 2016). Arctiinae represents one of the most nocturnal lepidopterans used as bioindicators because it responds quickly to environmental changes, is usually abundant, is easily sampled with light traps and its taxonomy is relatively well known (Kitching et al. 2000). Although these moths form a diverse and relatively well studied group, little is known about basic aspects of their natural history in the Neotropical region, such as larvae diet and time of activity of adults.

The main objective of this work was to investigate how the abundance and species richness of Arctiinae moths vary temporally, during the night. Specifically, we analyzed the following questions: (1) is there a relationship between the abundance and the species richness with the relative air humidity and with the temperature? (2) what is the time of activity of each specie of moth? (3) does the species composition differ over the night? (4) is it necessary to sample this group of moths throughout the night to have a representative sample of the species?

\section{Material and Methods}

We sampled the moths in Emas National Park (ENP), located in Brazil, State of Goiás, between Mineiros and Chapadão do Céu cities $\left(17^{\circ} 49^{\prime}-18^{\circ} 28^{\prime} \mathrm{S}\right.$ and $\left.52^{\circ} 39^{\prime}-53^{\circ} 10^{\prime} \mathrm{W}\right)$. We selected seven sampling points (Table 1, Figure 1) in an area of "campo cerrado", one of the

Table 1. Sampling dates, geographical coordinates, altitudes, and climatic conditions of the seven sample points of this study (Emas National Park, GO, Brazil).

\begin{tabular}{|c|c|c|c|c|c|}
\hline Sampling points & Sampling date & $\begin{array}{l}\text { Geographic } \\
\text { coordinates }\end{array}$ & Altitude (m) & $\begin{array}{c}\text { Average } \\
\text { temperature }\left({ }^{\circ} \mathrm{C}\right)\end{array}$ & $\begin{array}{c}\text { Average relative } \\
\text { humidity }(\%)\end{array}$ \\
\hline 1 & $13 / 12 / 2012$ & $\begin{array}{c}\mathrm{S} 17 \circ 55^{\prime} 26.4^{\prime \prime} \mathrm{W} 53^{\circ} \\
00^{\prime} 20.3^{\prime \prime}\end{array}$ & 871 & 19.9 & 86 \\
\hline 2 & $14 / 12 / 2012$ & $\begin{array}{c}\mathrm{S} 17 \circ 55^{\prime} 35.8^{\prime \prime} \mathrm{W} 53^{\circ} \\
00^{\prime} 19.3^{\prime \prime}\end{array}$ & 870 & 20.7 & 89 \\
\hline 3 & $15 / 12 / 2012$ & $\begin{array}{c}\mathrm{S} 17 \circ 55^{\prime} 44.1^{\prime \prime} \mathrm{W} 53^{\circ} \\
00^{\prime} 17.5^{\prime \prime}\end{array}$ & 871 & 20.0 & 88 \\
\hline 5 & $17 / 12 / 2012$ & $\begin{array}{c}\mathrm{S} 17 \circ 56^{\prime} 02.0^{\prime \prime} \mathrm{W} 53^{\circ} \\
00^{\prime} 15.1 "\end{array}$ & 875 & 20.7 & 86 \\
\hline 6 & $18 / 12 / 2012$ & $\begin{array}{c}\mathrm{S} 17 \circ 56^{\prime} 15.0^{\prime \prime} \mathrm{W} \\
53 \circ 00^{\prime} 14.3^{\prime \prime}\end{array}$ & 865 & 20.5 & 84 \\
\hline
\end{tabular}




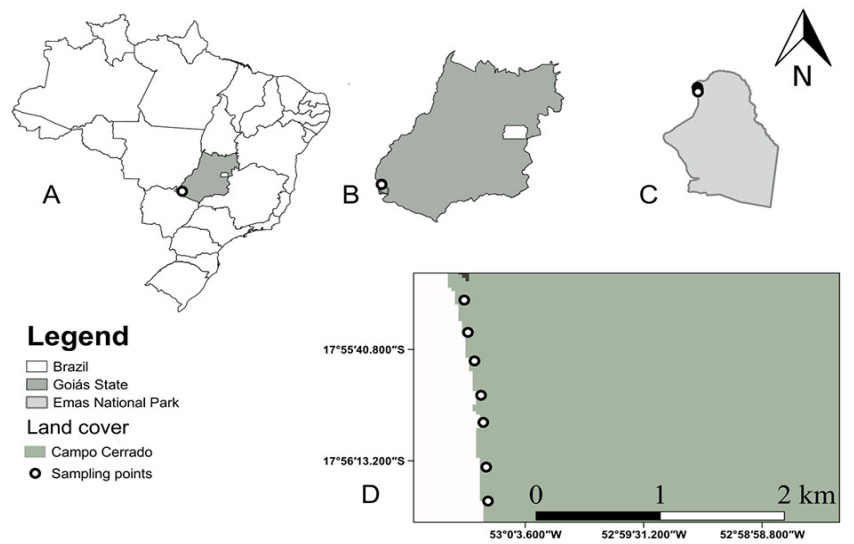

Figure 1. Map showing the points in which we sampled the Arctiinae moths Each point was sampled at one different night. A - Location of sampling points (circle) in Brazil. B - Location of the sampling points (circle) in the state of Goiás (gray). C - Location of the sampling points (circle) in the Emas National Park (gray). D - Location of the 7 sampling points (circles) in an area of "campo cerrado" of the Emas National Park (gray)

physiognomies of Cerrado biome. In each sampling point, we sampled the Arctiinae moths with a light trap (with a 15 -W black light fluorescent light bulb), reflected in a white cloth $(2 \times 3 \mathrm{~m})$ extended vertically.

We sampled the moths during seven consecutive nights (one point per night, from December 13 to December 19, 2012) of new moon phase, because in this moon phase the nights are darker, and therefore the attraction radius of the light trap is higher (Yela \& Holyoak 1997). The samplings were performed in December because it is summer in Brazil, the nights are not so cold, and the chances to collect moths in an open area such as campo cerrado are higher than in colder nights. We divided the night sampling in twelve periods of one hour each. The night of sampling started at $7 \mathrm{p} . \mathrm{m}$. and ended at $7 \mathrm{a}$. $\mathrm{m}$. of the next day. We measured the temperature and the relative humidity in each of the 12 sampling periods with a digital termohigrometer. The sampled moths were sorted to the lowest taxonomic level possible by comparison with the reference collection (UFG Zoological Collection), with the published literature (Watson \& Goodger 1986, Piñas-Rubio et al. 2000, Piñas-Rubio \& Manzano 2003), and with the types at V. O. Becker collection (Camacan, Brazil). All individuals were deposited in the UFG Zoological Collection (Goiânia, GO).

We tested the relationship between Arctiinae abundance and Arctiinae species richness with the climate variables through multiple regressions. In order to test the existence of a concentrate pattern on the peaks of abundance and richness of moths over the night, we performed a circular analysis (Rayleigh test) (Zar 1996). We performed the multiple regressions in the $\mathrm{R}$ program ( $\mathrm{R}$ Core Team 2018) and the circular analysis in the Oriana program (Kovach Computing Services 2011).

\section{Results}

We sampled 149 individuals belonging to 17 species of Arctiinae moths in the seven nights of sampling. The most abundant specie was Phoenicoprota baeri (Rothschild, 1911), with 70 individuals, followed by Leucanopsis annulosa (Walker, 1855) (22), Phoenicoprota sp.1 (19), and Agylla sp. 1 (six individuals).

Most species (12 species, 70.5\%) was active only for one or two hours over the night (Table 2$)$. Three species (17.5\%) were active for four or five hours, and only two species (12\%) were active for nine or ten hours over the night.

The species differed in terms of activity time. Dycladia lucetius (Stoll, 1781), Utetheisa ornatrix (Linnaeus, 1758), Agylla argentifera (Walker, 1866), Pheia seraphina (Herrich-Schaffer, 1854) and Pheia albisigna (Walker, 1854) were present in the early evening only. Amaxia dyuna Schaus, 1896, Idalus citrina Druce, 1890, Melese dorothea (Stoll, 1782), Aclytia heber (Cramer, 1780) and Cosmosoma restrictum Butler, 1876 occurred at the end of the night only. Phoenicoprota baeri Rothschild, 1911 and Lophocampa annulosa (Walker, 1855) were active throughout the night (Table 2).

The Arctiinae abundance was higher at the beginning of the night (Figure 2, Table 2). The circular analysis confirmed that the abundance is concentrated over time $(r=0.70, Z=73.11, p<0.001)$. The hour with the highest abundance was 8 p. m (44 individuals), followed by 9 p. m. (38) and 10 p. m. (23 individuals).

The species richness was also higher at the first hours of the night (Figure 2, Table 2), which was also concentrated over time $(r=0.62, \mathrm{Z}$ $=19.35, \mathrm{p}<0.001)$. The hour with the highest richness was $10 \mathrm{p} . \mathrm{m} .(10$ species), followed by 8 p. m (eight species) and 9 p. m. (five species).

The relative humidity of the air ranged from 78 to $90 \%$ during the seven nights of samplings (Table 3 ). However, the average humidity per hour practically did not vary (87-88\%) (Table 3, last column). The temperature, on the other hand, varied from 15 to $23.9^{\circ} \mathrm{C}$ throughout the seven nights of samplings (Table 4 ). The mean temperature per hour ranged from 18.2 to $20.7^{\circ} \mathrm{C}$, showing a decreasing trend as the night progressed (Table 4, last column).

There was a positive and significative relationship between the moth abundance and the temperature $\left(\mathrm{R}^{2}=0.09, \mathrm{~F}=4.009, \mathrm{p}=0.01\right)$. However, there was no significant relationship between moth abundance and relative humidity $\left(\mathrm{R}^{2}=0.002, \mathrm{~F}=1.67, \mathrm{p}=0.62\right)$. The Arctiinae species richness was neither influenced by temperature $\left(\mathrm{R}^{2}=0.04, \mathrm{~F}=3.05\right.$, $\mathrm{p}$ $=0.08)$ nor by the relative humidity $\left(\mathrm{R}^{2}=0.001, \mathrm{~F}=0.12, \mathrm{p}=0.72\right)$.

\section{Discussion}

We sampled only $11.4 \%$ of the Arctiinae species already registered in Emas National Park (Moreno \& Ferro 2016). However, our sampling effort was much lower than the study of Moreno \& Ferro (2016). In this study, we sampled two species of Arctiinae that were new records to Emas National Park: Agylla argentifera, and Phoenicoprocta sp. 2 (Moreno et al. 2014, Moreno \& Ferro 2016, Moreno et al. 2016). The majority of the Arctiinae moths sampled belong to the tribe Arctiini, a common pattern for this group in Cerrado biome (Moreno et al. 2014, Moreno \& Ferro 2016, Moreno et al. 2016).

Arctiinae abundance and species richness were higher at the beginning of the night. These results are in agreement with the study of Scherrer et al. (2013), who also observed higher abundances and richness of Arctiinae in the first hours of the night. However, the richness of Sphingidae moths were practically constant throughout the night and their abundance was higher in the beginning (7-9 p.m.), in the middle (0-2 a.m.) and at the end (4-5 a.m.) of the nocturnal period (Camargo et al. 2016). Thus, it is important to search for the hours of activity of the interest taxa to improve the chances of sampling a higher quantity of individuals and species. If our effort was to sample only in the first hours of the night (Scalercio et al. 2008), we would not have collected 
Moreno, C. et al.

Table 2. Number of individuals of Arctiinae sampled throughout the night (from 7 p.m. to 7 a.m.) in Emas National Park, GO, Brazil.

\begin{tabular}{|c|c|c|c|c|c|c|c|c|c|c|c|c|c|}
\hline & $\begin{array}{c}7 \\
\text { p.m. }\end{array}$ & $\begin{array}{c}8 \\
\text { p.m. }\end{array}$ & $\begin{array}{c}9 \\
\text { p.m. }\end{array}$ & $\begin{array}{c}10 \\
\text { p. m. }\end{array}$ & $\begin{array}{c}11 \\
\text { p.m. }\end{array}$ & $\begin{array}{c}0 \\
\text { a. m. }\end{array}$ & $\begin{array}{c}1 \\
\text { a.m. }\end{array}$ & $\begin{array}{c}2 \\
\text { a.m. }\end{array}$ & $\begin{array}{c}3 \\
\text { a.m. }\end{array}$ & $\begin{array}{c}4 \\
\text { a.m. }\end{array}$ & $\begin{array}{c}5 \\
\text { a.m. }\end{array}$ & $\begin{array}{c}6 \\
\text { a.m. }\end{array}$ & Total \\
\hline \multicolumn{14}{|l|}{ Arctiini } \\
\hline \multicolumn{14}{|l|}{ Callimorphina } \\
\hline \multicolumn{14}{|l|}{ Ctenuchina } \\
\hline Aclytia heber (Cramer, 1780) & & & & & & & & & & 1 & & & 1 \\
\hline Cosmosoma restrictum Butler, 1876 & & & & & & & & & & 1 & & & 1 \\
\hline Dycladia lucetius (Stoll, 1781) & & 2 & & 1 & & & & & & & & & 3 \\
\hline Pheia albisigna (Walker, 1854) & & & 2 & & & & & & & & & & 2 \\
\hline Pheia seraphina (Herrich-Schaffer, 1854) & & 2 & & 1 & & & & & & & & & 3 \\
\hline Phoenicoprota baeri Rothschild, 1911 & 1 & 26 & 28 & 6 & 2 & 2 & 1 & 2 & & 1 & & 1 & 70 \\
\hline Idalus carinosa (Schaus, 1905) & & 1 & 1 & 2 & & & & & & & & 1 & 5 \\
\hline Idalus citrina Druce, 1890 & & & & & & & & & & & 1 & 3 & 4 \\
\hline Lophocampa annulosa (Walker, 1855) & & 3 & & 2 & 1 & & 2 & 1 & 1 & 6 & 3 & 3 & 22 \\
\hline Melese dorothea (Stoll, 1782) & & & & & & & & & & & 1 & & 1 \\
\hline \multicolumn{14}{|l|}{ Lithosiini } \\
\hline \multicolumn{14}{|l|}{ Lithosina } \\
\hline Agylla argentifera (Walker, 1866) & & & & 1 & & & & & & & & & 1 \\
\hline Agylla sp. 1 & & & & 2 & & & 1 & & 2 & 1 & & & 6 \\
\hline Total abundance & 2 & 44 & 38 & 23 & 3 & 2 & 5 & 4 & 3 & 10 & 7 & 8 & 149 \\
\hline Total richness & 2 & 8 & 5 & 10 & 2 & 1 & 4 & 3 & 2 & 5 & 4 & 4 & 17 \\
\hline
\end{tabular}

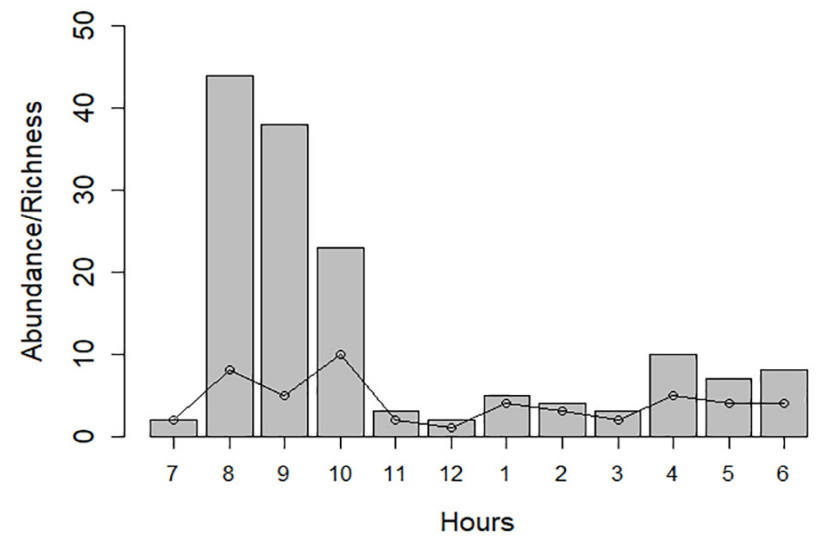

Figure 2. Abundance (bars) and richness (line) of Arctiinae moths throughout the night. The samples were performed in an area of savanna in Emas National Park (GO, Brazil), from December 13 to December 19, 2012

almost $30 \%$ of the species and $25 \%$ of the individuals of this study. Thus, in response to our fourth question, we suggest that rapid inventories or characterization of nocturnal Arctiinae fauna should be carried out throughout the night to raise the chances to capture the majority of species that fly in different periods.

There was a positive (even though low) and significative relationship between the moths' abundance and the temperature. This relationship was also observed in butterflies of Brazilian Atlantic Forest (Ribeiro et al. 2010), in butterflies of Ecuadorian Amazon (Checa et al. 2009), adult lepidopterans from Cerrado biome (Oliveira \& Frizzas 2008), Noctuidae and Geometridae moths from Czech Republic (Holyoak et al. 1997) and insects in general (Silva et al. 2011). The temperature is one of the main abiotic factors that influence insects in a direct (i.e. survivorship, time of development, fecundity, longevity, color patterns, and movement) and in an indirect way (i.e. abundance, occurrence, nutritional quality and defense of their hosts, as well as the abundance and occurrence of their natural enemies) (Checa et al. 2009, Ribeiro et al. 2010). The relative humidity of the air, however, was not related to the abundance or richness of moths. A possible explanation for this result is that the humidity did not vary much throughout the night (average relative humidity varied only $1 \%$ per hour).

More than $70 \%$ of the species were active for a very short period of time (one to two hours). A similar result was found by Scherrer et al. (2013), who observed that $80 \%$ of Arctiinae species were active for a maximum of three hours. The species of moths also differed in terms of time of activity. Some of them were observed at the beginning of the night only, some at the end, and others throughout the night. These differences in terms of activity times can be explained by intrinsic (such as sensory system, thermoregulation mechanism, body size, sexual and nutritional status of species) or by extrinsic factors (such as competition, predation and temperature). The temporal escape of natural enemies was the variable that best explained the seasonal pattern of abundance of lepidopteran caterpillars in the Cerrado biome (Morais et al. 1999). Likewise, we point out that the pressure of predation by bats may be one 
Table 3. Variation of the relative humidity throughout the night at the sampling points, located in a savanna area of the Emas National Park, GO, Brazil. The sample period was from December 13 to December 19, 2012.

\begin{tabular}{|c|c|c|c|c|c|c|c|c|}
\hline Hour & Point 1 & Point 2 & Point 3 & Point 4 & Point 5 & Point 6 & Point 7 & Average temperature \\
\hline 7 & 22.1 & 21.3 & 22.6 & 21.8 & 23.5 & 23.9 & 22.9 & 22.6 \\
\hline 8 & 21.3 & 21.3 & 23.3 & 18.2 & 19.9 & 23.5 & 21.3 & 21.3 \\
\hline 10 & 19.7 & 20.9 & 23 & 19.2 & 20.6 & 21.4 & 20.3 & 20.7 \\
\hline 11 & 19.6 & 20.5 & 22.1 & 18 & 20.8 & 22.2 & 20 & 20.5 \\
\hline 2 & 19.8 & 20.5 & 15.2 & 19 & 23.1 & 18 & 19 & 19.2 \\
\hline 3 & 19.7 & 20 & 16.8 & 17 & 20.7 & 18.2 & 18 & 18.6 \\
\hline 4 & 19 & 21.5 & 18.5 & 16 & 20 & 18.5 & 16.1 & 18.5 \\
\hline 5 & 18 & 20.2 & 18.2 & 17 & 20 & 18.9 & 15.1 & 18.2 \\
\hline
\end{tabular}

Table 4. Variation of temperature throughout the night at the sampling points, located in a savanna area of the Emas National Park, GO, Brazil. The sample period was from December 13 to December 19, 2012.

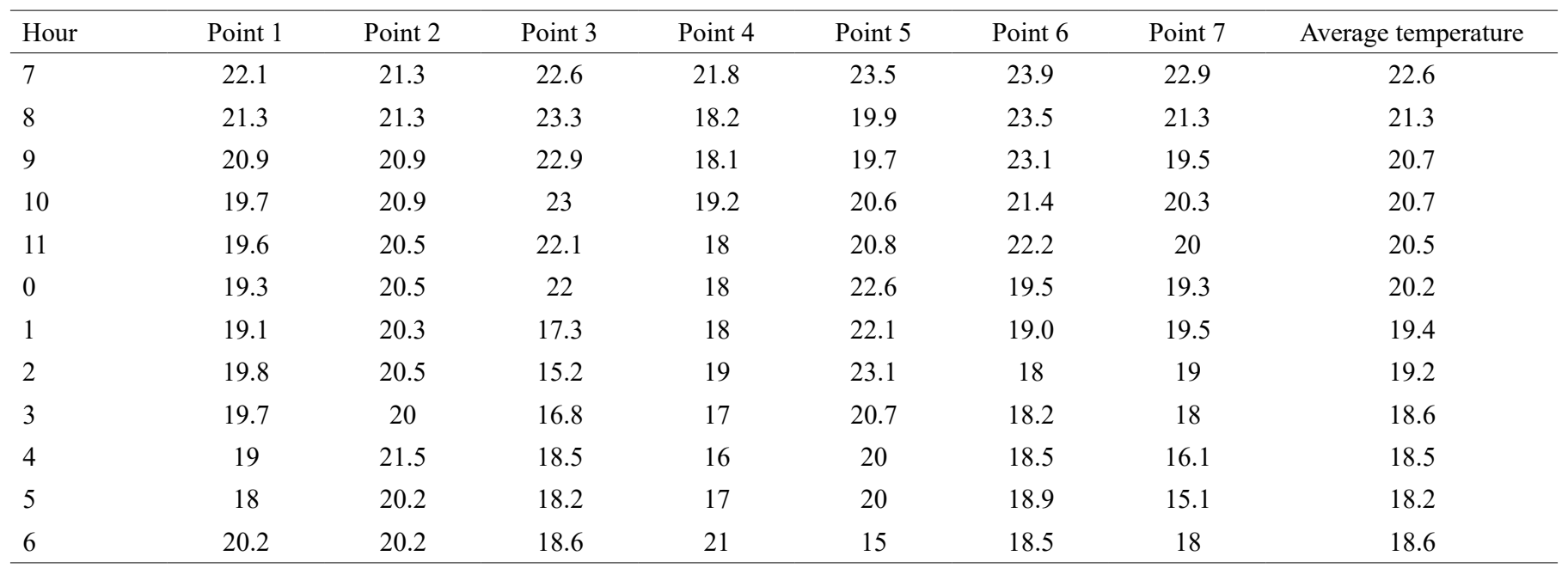

of the main biotic factors responsible for the time of activity observed in adult tiger moths, even though many Arctiinae species developed ways to avoid the predation by bats (Barber \& Conner 2007, Corcoran et al. 2009). Some species of insectivorous bats, which are important predators of moths (Barber \& Conner 2007, Corcoran et al. 2009), have their peak of activity at the end of the night (Emrich et al. 2014). We observed an opposite pattern for Arctiinae, which were more abundant in the early evening. Bats produce ultrasound when they are hunting for their prey. In response, several Arctiinae species also emit ultrasound to confuse or to alert their natural enemies about their toxicity (Conner 1999, Hristov \& Conner 2005, Barber \& Conner 2007, Corcoran et al. 2009). However, we do not know if the majority of the Neotropical Arctiinae species emitted effective sounds to be protected against the hunting of bats. Thus, the period of time in which Arctiinae forage might reflect their avoidance to be found by their natural enemy. As the 12 genera sampled in our study vary in terms of size, color pattern, and phylogenetic proximity, we expect that there will also be variation in terms of chemical and acoustic defense mechanisms against predators and that some species will use the temporal predatory escape strategy in daily periods. In addition to predation, the temperature, as discussed above, significantly influences various aspects of the moths'life history, such as defense (as it can accelerate or delay the development time), locomotion pattern (through thermoregulation) and population dynamics (Checa et al. 2009, Ribeiro et al. 2010).

The niche temporal partition can facilitate the coexistence of species by reducing overlapping resources, decreasing competition. As Devries et al. (2008) suggested, we agree that it is unlikely that the food resource (nectar) for most adults is a limiting factor. Thus, competition is not the main reason these species forage in distinct periods of the night. However, the use of flowers as a nectar resource for Arctiinae species is poorly known. We suggest that more studies on basic biology should be performed for this group of species, mainly in tropical environments.

\section{Acknowledgements}

We would like to thank Karen Neves, Amanda Honório, Silas Bittencourt, Balwer Pimentel, Fernanda Gonçalves, and Verônica Bernadino for help in the fieldwork. This study was funded by Site 13 
(Parque Nacional das Emas) of the Brazilian Long Term Ecological Research Network (CNPq, 558187/2009-9) and by RedeLep (CNPq, 563332/2010-7).

\section{Author Contributions}

Carolina Moreno: contributed with data acquisition; data analyses; manuscript preparation.

Ângela S. Barbosa: contributed with data acquisition; data analyses; manuscript preparation.

Viviane G. Ferro contributed with data acquisition; data analyses; manuscript preparation.

\section{Conflicts of interest}

The authors declare that they have no conflict of interest related to the publication of this manuscript.

\section{References}

AXMACHER, J.C., BREHM, G., HEMP, A., TUNTE, H., LYARUU, H.V.M., MULLER-HOHENSTEIN, K. \& FIEDLER, K. 2009. Determinants of diversity in afrotropical herbivorous insects (Lepidoptera: Geometridae): plant diversity, vegetation structure or abiotic factors? J. Biogeogr. 36: 337-349.

BARBER, J.R. \& CONNER, W.E. 2007. Acoustic mimicry in a predator-prey interaction. PNAS 104: 9331-9334.

CAMARGO, A.J.A., CAMARGO, N.F., CORREAA, D.C.V., CAMARGO, W.R.F., VIEIRA, E.M., MARINI-FILHO, O. \& AMORIM, F.W. 2016. Diversity patterns and chronobiology of hawkmoths (Lepidoptera, Sphingidae) in the Brazilian Amazon rainforest. J Insect Conserv 20: 629-641.

CHECA, M.F., BARRAGAN, A., RODRIGUEZ, J. \& CHRISTMAN, M. 2009 Temporal abundance patterns of butterfly communities (Lepidoptera: Nymphalidae) in the Ecuadorian Amazonia and their relationship with climate. Ann. Soc. Entomol. Fr. 45(4): 470-486.

CONNER, W.E. 1999. 'Un chant d'appel amoureux': acoustic communication in moths. J. Exp. Biol. 202: 1711-1723.

CORCORAN, A.J. BARBER, J.R. \& CONNER, W.E. 2009. Tiger moth jams bat sonar. Science 325: 325-327.

DEVRIES, P.J.; AUSTIN, G.T. \& MARTIN, N.H. 2008. Diel activity and reproductive isolation in a diverse assemblage of Neotropical skippers (Lepidoptera: Hesperiidae). Biol. J. Linnean Soc. 94: 723-736.

EMRICH, M.A., CLARE, E.L., SYMONDSON, W.O.C., KOENIG, S.E. \& FENTON, M.B. 2014. Resource partitioning by insectivorous bats in Jamaica. Mol. Ecol. 23: 3648-3656.

FERRO, V.G. \& DINIZ, I.R. 2010. Riqueza e composição das mariposas Arctiidae (Lepidoptera) no Cerrado. In Cerrado: conhecimento quantitativo como subsídio para as ações de conservação (I.R. Diniz, J. Marinho-Filho, R.B. Machado \& R. Cavalcanti, eds.). Editora Thesaurus, Brasília, p.255-313.

FERRO, V.G.; MELO, A.S. \& DINIZ, I.R. 2010. Richness of tiger moths (Lepidoptera: Arctiidae) in the Brazilian Cerrado: how much do we know? Zoologia 27: 725-731.

GUSMÃO, M.A.B., \& CREÃO-DUARTE, A.J. 2004. Diversidade e análise faunística de Sphingidae (Lepidoptera) em área de brejo e caatinga no estado da Paraíba, Brasil. Rev. Bras. Zool. 21: 491-498.

HEPPNER, J.B. 1991. Faunal regions and the diversity of Lepidoptera. Trop. Lep. 2: 1-85.

HILT, N., BREHM, G., \& FIEDLER, K. 2007. Temporal dynamics of rich moth ensembles in the montane forest zone in Southern Ecuador. Biotropica 39: 94-104.
HOLYOAK M., JAROSIK, V. \& NOVAK, I. 1997. Weather-induced changes in moth activity bias measurement of long-term population dynamics from light trap samples. Entomol. Exp. Appl., 83:329-335.

HRISTOV, N. \& CONNER, W.E. 2005. Sound strategy: acoustic aposematism in the bat-tiger moth arms race. Naturwissenschaften 92(4): 164-169.

KITCHING, R. L.; ORR, A. G.; THALIB, L.; MITCHELL, H.; HOPKINS, M.S. \& GRAHAM, A.W. 2000. Moth assemblages as indicators of environmental quality in remnants of upland Australian rain forest. J. Appl. Ecol. 37: 284-297.

KOVACH COMPUTING SERVICES 2011 Oriana version 3. Available online at: http://www.kovcomp.com/index.html

MINISTÉRIO DA AGRICULTURA E REFORMA AGRÁRIA 1992. Normas Climatológicas. Secretaria Nacional de Irrigação. Departamento Nacional de Meteorologia. Embrapa, Planaltina, p. 84

MORAIS, H.C.; DINIZ, I.R. \& SILVA, D.M.S. 1999. Caterpillar seasonality in a central Brazilian cerrado. Rev. Biol. Trop. 47: 1025-1033.

MORENO, C., CIANCIARUSO, M.V., SGARBI, L.F. \& FERRO, V.G. 2014. Richness and composition of tiger moths (Erebidae: Arctiinae) in Neotropical savanna: are heterogeneous habitats richer in species? Natureza \& Conservação 12: 138-143.

MORENO, C. \& FERRO, V.G. 2016. Arctiinae moths (Lepidoptera, Erebidae) of the Emas National Park, Goiás, Brazil. Biota Neotrop. 16(2): 1-9.

MORENO, C., LANDEIRO, V.L. \& FERRO, V.G. 2016. Plant species richness as the main driver of moth Metacommunities. Ecol. Entomol. 41: 707-715.

OLIVEIRA, C.M. \& FRIZZAS, M.R. 2008. Insetos de Cerrado: distribuição estacional e abundância. Boletim de Pesquisa e Desenvolvimento, edição 216. Planaltina, Embrapa Cerrados.

PIÑAS-RUBIO, F.S.J., RAAB-GREEN, S., ONORE, G., MANZANO, I. 2000. Mariposas Del Ecuador: Family Arctiidae. Quito: Pontifícia Universidade Católica Del Ecuador.

PIÑAS-RUBIO, F. \& MANZANO, P.I. Mariposas del Ecuador. Arctiidae. Subfamília: Ctenuchinae. Conpañia de Jesús. 2003.

PINHEIRO, F.; DINIZ; I.R., COELHO, D. \& BANDEIRA, M.P.S. 2002. Padrão sazonal da abundância de insetos no cerrado brasileiro. Austral Ecol. 27: 132-136.

RAMOS-NETO, M.B. \& PIVELLO, V.R. 2000 Lightning fires in a Brazilian Savanna National Park: rethinking management strategies. Environ. Management 26: 675-684

RIBEIRO, D.B., PRADO, P.I., BROWN K.S. \& FREITAS, A.V.L. 2010. Temporal diversity patterns and phenology in fruit-feeding butterflies in the Atlantic Forest. Biotropica 42(6): 710-716.

SCALERCIO, S., INFUSINO, M. \& WOIWOD, I.P. 2008. Optimising the sampling window for moth indicator communities. J. Insect Conserv. 13: 583-591.

SCHERRER, S., FERRO, V.G., RAMOS, M.N., \& DINIZ, I.R. 2013. Species composition and temporal activity of Arctiinae (Lepidoptera: Erebidae) in two cerrado vegetation types. Zoologia 30: 200-210.

SCOBLE, M. J. 1995. The Lepidoptera: from, function and diversity. New York, Oxford University Press.

SILVA, F.A.M., ASSAD, E.A. \& EVANGELISTA, B.A. 2008. Caracterização climática do bioma Cerrado. In Cerrado: ecologia e flora (S.M. Sano; S.P. Almeida; J.F. Ribeiro, eds.). vol. 2. Embrapa Informação Tecnológica, p. 69-88.

SILVA, N. A. P.; FRIZZAS, M.R. \& OLIVEIRA, C.M. 2011. Seasonality in insect abundance in the "Cerrado" of Goiás State, Brasil. Rev. Bras. Entomol. 55: 79-87. 
VAN NIEUKERKEN, E.J., KAILA, L., KITCHING, I.J., KRISTENSEN, N.P., LEES, D.C., MINET, J., MITTER, C., MUTANEN, M., REGIER, J.C., SIMONSEN, T.J., WAHLBERG, N., YEN, S-H., ZAHIRI, R., ADAMSKI, D., BAIXERAS, J., BARTSCH, D., BENGTSSON, B.A., BROWN, J.W., BUCHELI, S.R., DAVIS, D.R., DE PRINS, J., DE PRINS, W., EPSTEIN, M.C., GENTILI-POOLE, P., GIELIS, C., HÄTTENSCHWILER, P., HAUSMANN, A., HOLLOWAY, J.D., KALLIES, A., KARSHOLT, O., KAWAHARA, A.Y., KOSTER, S., KOZLOV, M.V., LAFONTAINE, J.D., LAMAS, G., LANDRY, J-F., LEE, S., NUSS, M., PARK, K-T., PENZ, C., ROTA, J., SCHINTLMEISTER, A., SCHMIDT, B.C., SOHN, J-C., SOLIS, M.A., TARMANN, G.M., WARREN, A.D., WELLER, S., YAKLOVLEV, R.V., ZOLOTUHIN, V.V. \& ZWICK, A. 2011: Order Lepidoptera Linnaeus, 1758. p. 212-221. In Animal biodiversity: an outline of higher-level classification and survey of taxonomic richness (Z.Q. Zhang, ed.). Zootaxa 3148: $1-237$.

WATSON, A. \& GOODGER, D.T. 1986. Catalogue of the Neotropical tigermoths. Occas. Pap. Syst. Entomol. 1: 1-70.
WELLER, S., DACOSTA, M. SIMMONS, R., DITTMAR, K., \& WHITING, M. 2009. Evolution and taxonomic confusion in Arctiidae. In Tiger Moths and Wolly Bears, Behavior, Ecology and Evolution of the Arctiidae (W.E. Conner ed.). Oxford University Press, New York, USA, p. 11-30.

WOLDA, H. 1978. Seasonal fluctuations in rainfall, food and abundance of tropical insects. J. Anim. Ecol. 47: 369-381.

WOLDA, H. 1988. Insect seasonality: why? Annu. Rev. Ecol. Syst. 19: 1-18.

YELA, J.L. \& HOLYOAK, M. 1997. Effects of moonlight and meterological factors on light bait trap catches of Noctuid moths (Lepidoptera: Noctuidae). Environ. Entomol. 26: 1283-1290.

ZAR, J. H. 1996. Biostatistical analysis. Prentici-Hall Edition, New Jersey.

Received: 07/05/2020

Revised: 11/03/2021

Accepted: 16/03/2021

Published online: 19/04/2021 